\title{
UJI DAYA HAMBAT INFUS DAUN JAMBU BIJI (Psidium guajava L.) TERHADAP PERTUMBUHAN Shigella sp.
}

\author{
Dewi Arisanti ${ }^{1)}$ Effendi Rasyanto ${ }^{1)}$ Alfira Adam ${ }^{1)}$ \\ ${ }^{1)}$ Akademi Analis Kesehatan Muhammadiyah Makassar \\ Alamat Korespondensi: Harimuswarah@yahoo.co.id
}

\begin{abstract}
Abstrak
Uji Daya Hambat Infus Daun Jambu Biji (Psidium guajava L.) Terhadap Pertumbuhan Shigella sp. Shigella adalah bakteri Gram-negatif, nonmotile, dan merupakan kuman patogen usus yang dikenal sebagai agen penyebab penyakit disentri basiler. Bakteri ini menginfeksi saluran pencernaan dan menyebabkan berbagai gejala, dari diare, kram, muntah, dan mual, sampai komplikasi yang lebih serius. Pengobatan dapat dilakukan dengan cara mengonsumsi antibiotik. Namun antibiotik terkadang resisten, sehingga dicari alternative lain berupa tanaman tradisional. Penelitian ini bertujuan untuk mengetahui kemampuan infus daun jambu biji dalam menghambat pertumbuhan Shigella sp.Jenis penelitian ini adalah eksperirnen laboratorium dilakukan dengan metode difusi, dan masa inkubasi selama 24 jam pada suhu $37^{\circ} \mathrm{C}$. Ada 4 konsentrasi yang di uji yaitu $20 \%$, 40\%, 60\%, dan $80 \%$ b/v. Pada penelitian ini digunakan pembanding yaitu tetrasiklin sebagai control positif. Hasil penelitian ini menunjukkan bahwa infus daun jambu biji dengan konsentrasi $20 \%$ dan $40 \%$ tidak dapat menghambat prtumbuhan bakteri Shigella sp sedangkan pada konsentrasi $60 \%$ dan $80 \%$ dapat menghambat pertumbuhan Shigella sp. Dari hasil penelitian diharapkan daun jambu biji dapat digunakan sebagai obat alternatif dalam mengobati penyakit dan penelitian ini dapat dilanjutkan dengan menggunakan spesies bakteri lain dan pembuatan simplisia yang lain.
\end{abstract}

Kata Kunci: Infus Daun Jambu Biji, Shigella sp

\section{PENDAHULUAN}

Diare merupakan penyakit yang sampai saat ini masih menjadi masalah kesehatan masyarakat, walaupun secara umum angka kematian masih berfluktuasi, dan pada tahun 2013 tidak terjadi kematian akibat diare yang dilaporkan oleh sarana pelayanan dan kader kesehatan namun penyakit diare ini masih menjadi skala prioritas dalam kegiatan penanggulangannya. Kasus diare yang dilaporkan oleh 39 puskesmas seKota Makasaar sampai dengan Desember 2013 sebanyak 28.908 kasus. Angka kesakitan (Incidence Rate/IR) penyakit diare pada tahun 2013 angka ini menurun dari tahun 2012 dengan jumiah kasus 29.265 (Pemerintah Kota Makassar Dinas Kesehatan, 2014.

Pada umumnya diare disebabkan oleh virus, protozoa, bakteri yang memproduksi enterotoksin ( $S$. Aureus, Clostridium perfringens, E.coli, Vibrio cholera) dan yang menimbulkan inflamasi mukosa usus seperti Shigella sp. Shigella adalah bakteri Gram-negatif, nonmotile, dan merupakan kuman patogen usus yang dikenal sebagai agen penyebab penyakit disentri basiler. Bakteri ini menginfeksi saluran pencernaan dan menyebabkan berbagai gejala, dari diare, kram, muntah, dan mual, sampai komplikasi yang lebih serius (Jawetz, et.al, 2005).

Pengobatan diare dapat dilakukan dengan cara modern. Selain itu, pengobatan diare juga dapat dilakukan dengan cara tradisional. Cara tradisional, dilakukan dengan pemberian obat yang dibuat dari tumbuhan yang diolah dengan cara yang sangat sederhana dan membutuhkan tenaga manusia yang sangat besar. Keunggulan yang diperoleh dalam menggunakan ramuan tradisional, yaitu pada umumnya, harga ramuan tradisional lebih murah jika dibandingkan dengan obat-obatan buatan pabrik. Bahan ramuan tradisonal sangat mudah didapatkan disekitar lingkungan, bahkan 
dapat ditanam sendiri untuk persediaan keluarga, pengolahan ramuannya juga tidak rumit, sehingga dapat dibuat di dapur sendiri tanpa memerlukan peralatan khusus dan biaya besar.

Adapun obat diare tradisional yang sudah banyak membantu pasien terbebas dari masalah buang air besar berlebih, salah satunya adalah daun jambu biji. Karena dalam daun jambu biji ini terdapat senyawa tanin, eugenol ( minyak atsiri), minyak lemak, dammar, zat samak, triterpinoid, dan asam afel. Buahnya berkhasiat antioksidan dengan kandungan beta karoten disamping asam amino (triptofan, lisin ), kalsium, fosfor, besi, belerang, vitamin $\mathrm{A}$, vitamin $\mathrm{B} 1$, dan vitamin $\mathrm{C}$ yang tinggi. Namun, bagian tanaman yang sering digunakan sebagai obat adalah daunnya, karena daun jambu biji diketahui mengandung senyawa tannin 9-12\% (Hariana, A., 2012, Yuliana, S., 2001 ).

Berdasarkan

penelitian

sebelumnya, Nur Amriani Arifin (2011), dalam penelitiannya tentang uji daya hambat infus daun jambu biji (Psidium guajava $L$ ) terhadap pertumbuhan Eschericia coli. Diperoleh kesimpulan bahwa ekstrak daun jambu biji (Psidium guajava L.) dapat menghambat pertumbuhan bakteri Eschericia coli. Hal ini terlihat dengan adanya zona hambat sebesar $10 \mathrm{~mm}$ pada konsentrasi $20 \%$ sebagai konsentrasi terendah dan zona hambat $12 \mathrm{~mm}$ pada konsentrasi $80 \%$ sebagai konsentrasi tertinggi.

Berdasarkan uraian di atas, maka penulis ingin melakukan penelitian tentang uji daya hambat infus daun jambu biji (Psidium guajava L.) terhadap pertumbuhan Shigella $s p$. Adapun tujuan penelitian ini untuk mengetahui kemampuan infus daun jambu biji menghambat pertumbuhan Shigella $s p$. Degan adanya penelitian diharapkan kepada masyarakat agar dapat mengetahui manfaat/khasiat dari daun jambu biji bagi kesehatan.

\section{METODE PENELITIAN}

\section{Alat Dan Bahan}

Alat yang digunakan adalah Penangas Air, beaker glass, sendok tanduk, corong steril, Bunsen, batang pengaduk, cawan petri, pencadang, timbangan analitik, autoklaf, labu ukur, incubator, lemari es, mistar geser, ose bulat, rak tabung, pinset, pipet volume, oven dan tabung reaksi.

Bahan yang digunakan adalah daun jambu biji, Larutan Me. Farland 0,5, media Muller Hilton Agar, tetrasiklin, kain kasa, aquadest, koloni shigella $s p$, media NA (Nutrient Agar), Nacl fisiologis, NaCMC (Natrium Carboximethyle Cellulose) 1\%, dan kapas.

\section{Prosedur Penelitian \\ Persiapan sampel}

Sampel daun jambu biji (Psidium guajava L.) diambil dari Limbung, Kab. Gowa. Sampel yang diambil adalah daun ketiga sampai ke lima di bawah pucuk. Pengambilan sampel dilakukan pada pagi hari jam 07:00 - 09:00. Daun jambu biji dicuci bersih kemudian dipotong kecilkecil dan dikering anginkan. Daun jambu biji yang sudah dipotong-potong ditimbang sesuai konsentrasi infus yang akan dibuat. Untuk memperoleh infus dengan konsentrasi $80 \%$, daun jambu biji ditimbang sebanyak 80 gram dan dicukupkan dengan aquadest sebanyak $100 \mathrm{ml}$. Dipanaskan selama 15 menit, terhitung mulai suhu didalam panci infus mencapai suhu $90^{\circ} \mathrm{C}$ sambil sesekali diaduk. Setelah 15 menit, disaring dengan kain kasa steril dan ditampung dalam beaker glass. Diambil filtratnya untuk diuji. Hal yang sama dilakukan untuk pembuatan infus dengan konsentrasi $20 \%$ $40 \%, 60 \%$, dan $80 \%$.

\section{Pembuatan medium Muller Hilton Agar (MHA)}

Bahan yang akan digunakan ditimbang kemudian dilarutkan dalam aquades, dipanaskan pada hot plate agar semua bahan larut sempurna, lalu diukur 
pH-nya sampai 7,4 dan disterilkan pada autoklaf pada suhu $121{ }^{\circ} \mathrm{C}$ selama 15 menit. Setelah suhu media $50^{\circ} \mathrm{C}$, media dituang ke cawan petri $\pm 10 \mathrm{~mL}$ sebagai base layer. Setelah membeku, media \pm 10 $\mathrm{mL}$ yang telah disuspensikan bakteri Shigella $s p$ dituang di atas base layer. Lapisan ini merupakan seed layer. Kemudian diletakkan pencadang pada media setengah beku.

\section{Pengujian daya hambat}

Infus daun jambu biji (Psidium guajavai L.) diisi pada sumur (pencadang). Masing masing sumur diisi infus daun jambu biji konsentrasi $20 \%$, $40 \%, 60 \%, 80 \%$, kontrol positif dan kontrol negatif. Diinkubasi selama $1 \times 24$ jam pada suhu $37^{\circ} \mathrm{C}$. setelah 24 jam diukur daerah zona hambatan disekitar pencadang menggunakan mistar geser. Diameter zona hambat pertumbuhan bakteri menunjukkan sensitivitas bakteri terhadap zat anti bakteri. Zona hambat yang disebabkan oleh daun jambu biji dibandingkan dengan zona hambat yang terbentuk oleh kontrol positif (Tetrasiclin). Tetrasiklin dikatakan resisten apabila diameter zona hambat yang terbentuk $\leq 14 \mathrm{~mm}$, intermediate 15 $18 \mathrm{~mm}$ dan sensitive $\geq 19 \mathrm{~mm}$.

\section{HASIL PENELITIAN}

Hasil penelitian dari uji daya hambat infus daun jambu biji (Psidium guajava L) terhadap pertumbuhan Shigeila $s p$ dengan masa inkubasi selama 24 jam dengan konsentrasi yang berbeda yaitu $20 \%, 40 \%, 60 \%$, dan $80 \%$ dilakukan dengan $3 \mathrm{x}$ perlakuan. Hasil pengukuran diameter zona hambatan infus daun jambu biji (Psidium guajava L.) dapat dilihat pada table berikut:
Tabel 1. Hasil Pengukuran Diameter Zona Hambatan Infus Daun Jambu Biji (Psidium guajava L.) Terhadap Pertumbuhan Shigeila sp.

\begin{tabular}{|c|c|c|c|c|}
\hline \multirow{2}{*}{$\begin{array}{c}\text { Zat } \\
\text { Antibakteri }\end{array}$} & \multicolumn{3}{|c|}{$\begin{array}{l}\text { Diameter Zona Hambat } \\
(\mathrm{mm})\end{array}$} & \multirow{2}{*}{$\begin{array}{c}\text { Rata- } \\
\text { rata } \\
(\mathrm{mm})\end{array}$} \\
\hline & I & II & III & \\
\hline Daun & & & & \\
\hline $\begin{array}{l}\text { Jambu Biji } \\
(20 \%)\end{array}$ & 0 & 0 & 0 & 0 \\
\hline $\begin{array}{l}\text { Daun } \\
\text { Jambu Biji } \\
(40 \%)\end{array}$ & 0 & 0 & 0 & 0 \\
\hline $\begin{array}{l}\text { Daun } \\
\text { Jambu Biji } \\
(60 \%)\end{array}$ & 13,16 & 13,16 & 13,16 & 13,16 \\
\hline $\begin{array}{l}\text { Daun } \\
\text { Jambu Biji } \\
(80 \%)\end{array}$ & 16,66 & 18,33 & 15,33 & 16,77 \\
\hline $\begin{array}{l}\text { Tetracyclin } \\
(\mathrm{K}+)\end{array}$ & 20,66 & 20,16 & 20,16 & 20,33 \\
\hline $\begin{array}{l}\text { Aquadest } \\
(\mathrm{K}-)\end{array}$ & 0 & 0 & 0 & 0 \\
\hline
\end{tabular}

Keterangan : Diameter Pencadang $8 \mathrm{~mm}$

Hasil penelitian menunjukkan bahwa infus daun jambu biji (Psidium guajava L.) dapat menghambat pertumbuhan Shigella sp. Hal ini dapat dilihat dengan adanya hambatan pertumbuhan mikroba uji disekeliling pencadang oleh senyawa antibakteri yang terdapat pada infus daun jambu biji (Psidium guajava L). Pada peneiitian ini dilakukan uji daya hambat infus daun jambu biji (Psidium guajava $L$ ) terhadap pertumbuhan Shigella $s p$ dalam hal ini penyebab diare dengan menggunakan metode difusi agar berlapis.

Metode ini dilakukan untuk mengetahui besarnya diameter zona hambatan yang terbentuk. Hasil pengukuran diameter zona hambatan memperlihatkan bahwa infus daun muda jambu biji dengan konsentrasi 20\%, 40\%, $60 \%, 80 \%$ terhadap pertumbuhan Shigella $s p$. Dengan masa inkubasi 24 jam menunjukkan bahwa disekitar pencadang yang berisi infus daun jambu biji mengandung senyawa yang dapat menghambat pertumbuhan Shigella sp.

Hasil peneiitian menunjukkan bahwa pada infus daun jambu biji konsentrasi $20 \%$ dan $40 \%$ menunjukkan bahwa di sekitar pencadang tidak terbentuk zona bening yang merupakan 
daerah hambatan. Pada konsentrasi $60 \%$ menunjukkan bahwa di sekitar pencadang menghasilkan daerah tening atau zona hambatan dengan rata-rata sebesar 13,6 $\mathrm{mm}$. Sedangkan pada konsentrasi $80 \%$ menunjukkan bahwa disekitar pencadang menghasilkan daerah bening dengan ratarata zona hambatan sebesar 16,77. Hal ini menunjukkan bahwa konsentrasi daun jam biji dapat menghambat pertumbuhan Shigella sp adalah $60 \%$ dan $80 \%$. Semakin tinggi konsentrasi daun jambu biji maka semakin tinggi pula zona hambat yang terbentuk. Hal ini menandakan bahwa pada infus daun jambu biji terdapat senyawa aktif yang dapat menghambat pertumbuhan Shigella $s p$.

Dinding sel bakteri Gram negatif mempunyai dua lapisan luar yang tersusun dari lipopolisakarida dan protein dan lapisan dalam tersusun atas peptidoglikan. Adanya efek pengendapan dan denaturasi protein oleh tanin menyebabkan kerusakan pada dinding sel bakteri sehingga berbagai komponen penting dalam sel bakteri akan keluar dan lisis.

Penelitian ini dapat dilanjutkan dengan spesies bakteri yang lain karena kemungkinan dapat mengahambat pertumbuhan bakteri tersebut.

\section{KESIMPULAN}

Berdasarkan hasil penelitian yang dilakukan dapat disimpulkan bahwa infus daun jambu biji (Psidium guajava L.) dapat menghambat pertumbuhan bakteri uji Shigella $s p$. tinggi konsentrasi infus daun jambu biji pada penelitian ini maka daya hambatnya semakin besar.

\section{SARAN}

Disarankan untuk peneliti selanjutnya untuk melakukan penelitian lebih lanjut terhadap infus daun jambu biji (Psidium guajava L.) dengan konsentrasi yang lebih tinggi atau dengan menggunakan spesies bakteri lain.

\section{DAFTAR PUSTAKA}

Ditjen POM. 1979. Farmakope Indonesia, Edisi III. Jakarta: Departemen Kesehatan Republik Indonesia.
Ganiswarna .S .G, 2007. Farmakologi dan Terapi. Depok: Universitas Indonesia.

Mariana, A. 2012. Tumbuhan Obat dan Khasiatnya. Jakarta: Penebar swadaya.

Pemerintah Kota Makassar Dinas Kesehatan. 2014. Profit Kesehatan Kota Makassar 2013.

Irianto, K. 2006. Mikrobiologi Menguak Dunia Mikroorganisme, Edisi 1. Bandung: Yrama Widya.

Irianto, K. 2013. Mikrobiologi Medis. Bandung: Alfabeta.

Jawetz, et al. 2005. Mikrobiologi Kedokteran. Jakarta: Salemba Medika.

Jawetz, et al. 2001. Mikrobiologi Kedokteran. Jakarta: Salemba Medika

Kalokasari, D. M. 2012. Daya Hambat Ekstrak Daun Jambu Biji (Psidiumguajava Linn) Varian Putih Dalam Pasta Gigi Terhadap Pertumburtan Lactobacillus acidophilus. Jember: Universitas Jember.

Syah, A. 2011. Obat Herbal Luar Biasa. CV. Pustaka Agung Harapan. 